\title{
Analisis Prioritas Pengembangan Pariwisata di Desa Wisata Lebih, Kecamatan Gianyar, Kabupaten Gianyar
}

Annisa Melia Sumitapradja a, 1, I Putu Anom a, 2

1 anisamelia23@gmail.com, ${ }^{2}$ putuanom@unud.ac.id

a Program Studi S1 Destinasi Pariwisata, Fakultas Pariwisata,Universitas Udayana, Jl. Dr. R. Goris, Denpasar, Bali 80232 Indonesia

\begin{abstract}
Lebih Village is a village located in Gianyar subdistrict, Gianyar regency, famous for its coastal tourism, which is Lebih Beach. Lebih Village have been included in the criteria for Tourism Village, however, their certificate has not been issued for this year. In addittion to the coastal tourist attraction, it turns out that the village has more potentials to be developed into a tourist attraction. Theses potentials include a natural, cultural and artificial attraction. These potentials still need to be developed in order to run in the tourism sector. In connection with this, the author tries to examine the "Analisis Prioritas Pengembangan Pariwisata di Desa Wisata Lebih, Kecamatan Gianyar, Kabupaten Gianyar. The research method used in this research is qualitative research with qualitative descriptive analysis technique and SWOT analysis, to analyze the tourism development priorities in Lebih tourism village. The purpose of this study was to determine how the existing conditions and to find out the priority strategies for tourism development in Lebih Village. Sources of data from primary data and secondary data, data collection techniques using observation, interview and literature study, and interview instruments in the form of interview guidelines. The research of informant in Lebih Tourism Village in this research use purposive sampling technique, to get accurate data about tourism development priorities in Lebih tourism village, Gianyar subdistrict, Gianyar regency. The conclusion of this research is the exisiting condition in Lebih Village with component $4 A$ which explains the attractions, accsess, facilities, and additional services. In addition there is a main priority strategy for tourism development in Lebih Village which is to develop the potentials they have, collaborate with another stakeholders, conduct training for the community, build tourism facilities, conduct promotions and improve management. The results of this research is the strategies obtained by the SWOT analysis, which were used as a priorities development strategy of tourism in Lebih Tourism Village, Gianyar.
\end{abstract}

Keyword: Tourism Development Periorities, SWOT analysis, Tourism Village, Lebih Village.

\section{PENDAHULUAN}

Sejak dahulu Indonesia memiliki ragam kekayaan yang telah menjadi perhatian dunia. Seperti Bali sebagai destinasi wisata sudah sangat familiar di mata dunia internasional. Sektor pariwisata telah menjadi andalan pembangunan provinsi Bali sampai masa kini.

Tetapi, Bali selalu berupaya inovatif dengan mengeksplorasi potensi-potensi wisata baru. Daya tarik wisata di Bali ternyata belum sepenuhnya dikenal oleh wisatawan. Kondisi terakhir banyak desa wisata bermunculan dengan beragam produk wisata yang ditawarkan. Pengembangan desa wisata selayaknya harus didukung oleh masyarakat lokal untuk menciptakan visi, misi dan asas keberlanjutan. Aspek kelembagaan memiliki peran strategis sebagai wadah penggerak dalam fasilitasi dan partisipasi masyarakat (Mahagangga, 2018).

Kabupaten Gianyar, Proivinsi Bali telah terkenal seni dan bentang alamnya. Di Gianyar terdapat banyak desa wisata, dimana kegiatan wisata yang dilakukan yaitu menikmati kaindahan alam serta budayanya. Salah satu desa yang baru masuk kriteria sebagai Desa Wisata namun belum memiliku SK yaitu Desa Lebih. Desa lebih terkenal akan wisata pantainya yang bernama Pantai Lebih dengan banyak potensi lain belum direncanakan dengan baik.
Berdasarkan hal tersebut, maka peneliti tertarik untuk mengidentifikasi potensi Desa Lebih dalam mewujudkan strategi pengembangan dengan berfokus kepada prioritas pengembangan untuk kegiatan Desa Wisata.

Adapun ruang lingkup permasalahan dalam penelitian ini yaitu kondisi eksisting Desa Lebih berdasarkan komponen $4 \mathrm{~A}$ dan analisis prioritas pengembangan menggunakan analisis SWOT. Pendekatan pemecahan masalah dalam penelitian ini menggunakan penelitian kualitatif dengan teknik analisis deskriptif kualitatif dan analisis SWOT.

Dalam penelitian ini menggunakan beberapa konsep dan teori analisis yang sesuai dengan data dan topik yaitu, konsep desa wisata, konsep pengembangan pariwisata, teori pengembangan destinasi pariwisata, konsep prioritas, konsep potensi wisata, konsep daya tarik wisata, dan konsep pariwisata. Selain itu, terdapat telaah hasil penelitian sebelumnya yang digunakan dalam penelitian ini. Penelitian pertama berjudul "Analisis SWOT untuk Strategi Pengembangan Obyek Wisata Pemandian Mual Mata Kecamatan Pematang Bandar Kabupaten Simalungun" yang dilakukan oleh Fitra Delita, Elfayetti, dan Tumiar Sidauruk (2012). Persamaannya yaitu sama-sama mengunakan analisis SWOT untuk menentukan strategi pengembangan. Penelitian kedua berjudul 
"Perencanaan Pengembangan Kawasan Pariwisata Pantai Lebih, Desa Lebih, Kabupaten Gianyar" oleh Ni Ketut Desi Ariani dan Ida Bagus Suryawan (2018). Persamaan penelitian sebelumnya dengan yang sekarang yaitu pada lokasi penelitian dan mengenai pengembangan pariwisata di Desa Lebih, Gianyar.

\section{METODE PENELITIAN}

Penelitian ini berlokasi di Desa Lebih, Kecamatan Gianyar, Kabupaten Gianyar. Jenis data yang digunakan dalam penelitian ini yaitu Data Kualitatif (Moleong, 2007) dan Data Kuantitatif (Kusumayadi dan Sugiarto, 2000). Sumber data yang digunakan yaitu Data Primer dan Data Sekunder (Sugiyono, 2008). Data primer dalam penelitian ini yaitu mengenai kondisi eksisting di Desa Lebih yang meliputi, atraksi, akses, fasilitas, dan kelembagaan yang ada di Desa Lebih, kekuatan dan kelemahan Desa Lebih, serta ancaman dan peluang di Desa Lebih. Teknik pengumpulan data yang digunakan yaitu Observasi (Arikunto, 2006), Wawancara (Bungin, 2007), dan Studi Kepustakaan (Moleong, 2012). Teknik penentuan informan dalam penelitian ini menggunakan Purposive Sampling (Bungin, 2012), dengan informan Kepala Desa, POKDARWIS, dan masyarakat Desa Lebih. Teknik analisis data yang digunakan dalam peneltian ini yaitu Analisis Kualitatif (Bungin, 2007) dan Analisis SWOT (Kotler dan Amstrong, 2008).

\section{HASIL DAN PEMBAHASAN \\ 3.1 Kondisi Eksisting}

Desa Lebih merupakan bagian dari wilayah Kecamatan Gianyar, Kabupaten Gianyar. Desa Lebih sudah lebih terkenal dengan wisata pantainya, yaitu Pantai Lebih. Pantai tersebut terletak di jalan Tohpati-Kusamba dimana banyak wisatawan yang mampir atau menghabiskan waktu untuk beristirahat sebelum melanjutkan perjalanan mereka. Selain itu banyak juga wisatawan yang berkunjung untuk berselancar, bermain di pantai dan juga di Pantai lebih terdapat wisata kuliner yang banyak diminati wisatawan.

Selain adanya pantai yang menjadi daya tarik wisata alam, di Desa Lebih terdapat potensi pariwisata lain yang jika dikembangkan dengan baik dapat menunjang perekonomian masyarakat desa. Potensi-potensi tersebut meliputi potensi wisata alam, potensi wisata budaya, serta potensi wisata buatan. Untuk mengetahui potensi-potensi tersebut serta untuk mengetahui hal-hal lain yang dimiliki Desa Lebih, maka terdapat beberapa komponen penting yaitu seperti, Atraksi (Attraction), Aksesibilitas (Accessibility), Fasilitas (Amenity), dan Kelembagaan (Ancilliary). Ke empat komponen tersebut juga dapat menjadi indikator dalam mendeskripsikan kondisi eksisting di Desa Lebih sebagai Desa wisata baru yang memiliki banyak potensi yang harus dikembangkan.

\section{Atraksi (Attraction)}

Atraksi utama di Desa Lebih yaitu Pantai Lebih. Pantai Lebih menyuguhkan keindahan pantai yang cukup luas serta terdapat wisata kuliner yang menjual berbagai olahan seafood yang tentunya menjadi atraksi wisata bagi wisatawan yang berkunjung. Selain pantai, terdapat atraksi menarik lain yang terdapat di Desa Lebih seperti, areal persawahan untuk dikembangkan menjadi jalur trecking dan cycling, disana ada hutan desa yang cukup luas yang rencana pengembangannya sebagai wisata edukasi mengenai tumbuhan dan hewan langka, selanjutnya ada sungai besar yang dapat dipakai untuk bermain kano, tubbing, tempat bermeditasi, dll, lalu disana terdapat peninggalan sejarah dan budaya seperti Cagar Budaya Pura Sibi Agung.

\section{Aksesibilitas (Accessibility)}

Aksesibilitas untuk menuju Desa Lebih dapat dikatakan sudah baik karena telah dilakukan pengaspalan. Untuk menuju ke Desa Lebih dapat melalui Jalan Bypass Ida Bagus Mantra yang menghubungkan antara Denpasar dengan Karangasem dan membutuhkan waktu sekitar 60 menit dari Ibu Kota Provinsi Bali. Selain melalui Jl. Bypass Ida Bagus Mantra, untuk menuju Desa Lebih dapat menggunakan jalan dalam kota yang dapat membutuhkan waktu tempuh sekitar 120 menit.

Sedangkan akses untuk menuju potensi-potensi Desa Lebih juga dapat dikatakan sudah cukup baik. Akses untuk menuju sawah dan lahan dapat dilalui dengan mudah walaupun jalannya tidak terlalu besar dan akses tersebut sudah tertata dan bersih. Namun untuk jalur yang akan digunakan trekking perlu adanya penataan lebih lanjut. Lalu akses untuk menuju ke hutan desa dapat dilalui dari berbagai arah, ada yang dari jalan raya ada juga akses dari dalam, yaitu dari arah sungai sang-sang. Untuk jalur dari dalam, jalur tersebut masih berupa jalan setapak yang lebih cocok dilewati oleh wisatawan yang sedang trekking. Untuk jalan setapak menuju hutan desa, jalurnya sudah ada namun perlu dirapikan dan diperjelas. Berikutnya yaitu akses menuju ke sungai, untuk menuju ke sungai salah satu jalurnya melalui rumah-rumah warga. Jalurnya juga sudah ada dan jelas namun perlu dibersihkan lagi. Sedangkan untuk potensi budaya dan sejarahnya, aksesnya dapat dilalui dari berbagai arah serta sudah tertata dengan baik.

\section{Fasilitas (Amenity)}

Untuk di Desa lebih fasilitas yang tersedia untuk kegiatan pariwisata dapat dikatakan masih kurang, masih perlu perencanaan lebih lanjut untuk dibangun homestay, toilet, tempat perbelanjaan, kios-kios untuk menjual hasil kerajinan, dsb. Namun untuk di Pantai Lebih, fasilitas yang tersedia yaitu 
berupa tempat makan yang menawarkan berbagai masakan olahan laut, lalu terdapat lahan parkir serta toilet namun fasilitas tersebut masih kurang tertata.

\section{Kelembagaan (Ancilliary)}

Kelembagaan di Desa Lebih terdapat desa dinas, BUMD, BUMDES, koprasi banjar, pengusaha wisata, pengusaha tempat makan, warung, warung, POKDARWIS, dan banjar desa. Semua stakeholder tersebut bekerjasama untuk mengembangkan potensi-potensi wisata di Desa Lebih yang tentunya memerlukan pengembangan lebih lanjut. Untuk pembangunan fisik sudah baik, sudah adanya jalan raya, terpenuhinya pasokan air minum serta air bersih, masuknya jaringan dan telepon, dan lain-lain. Lalu untuk kelembagaan juga sudah baik, namun untuk di sektor pariwisatanya sudah terdapat POKDARWIS.

\subsection{Analisis SWOT}

Dalam melakukakan Analisis SWOT, perlu dilakukan pemetaan empat unsur atau faktor penyusun SWOT, yaitu:

\section{Kekuatan (Strengths)}

Berdasarkan data yang diperoleh dari observasi, wawancara, dan sember - sumber data lainnya, maka adpun kekuatan yang dimiliki Desa Lebih antara lain :

a. Desa Lebih memiliki Daya Tarik Wisata Alam, yaitu Pantai Lebih yang sudah berkembang lebih dahulu.

b. Memiliki Potensi Wisata yang beragam yaitu, alam, budaya, buatan, serta sejarah

c. Sikap masyarakat yang mendukung adanya pengembangan pariwisata

d. Lokasi Desa Lebih yang strategis dan mudah dijangkau serta berdekatan dengan daya tarik wisata lain.

\section{Kelemahan (Weaknesses)}

Selain kekuatan, maka terdapat juga kelemahan atau kendala yang dimiliki Desa Lebih antara lain sebagai berikut :

a. Kurangnya dana yang diperlukan untuk mengembangkan pariwisata dan kurangnya promosi untuk Desa Lebih

b. Kurangnya akomodasi bagi wisatawan

c. Belum optimalnya sarana dan prasarana penunjang pariwisata

d. Kelompok Sadar Wisata atau POKDARWIS yang belum terlalu aktif

e. Kurangnya pemahaman masyarakat Desa Lebih akan cara pengembangan potensi yang dimiliki

\section{Peluang (Opportunities)}

a. Tren desa wisata yang berbasiskan alam dan budaya

b. Berdekatan dengan daya tarik wisata lain

c. Perkembangan Teknologi, Informasi dan Komuikasi yang semakin maju dan mudah diakses d. Terciptanya lapangan pekerjaan baru bagi masyarakat sekitar

\section{Ancaman (Threats)}

a. Kondisi Global yang tidak stabil, yaitu terjadinya Global Warming

b. Pengembangan kawasan pariwisata pesisir yang semkin banyak

c. Pengaruh bagi kehidupan budaya dan adat istiadat masyarakat Desa Lebih

Setelah melakukan pemetaan empat unsur atau faktor penyusun SWOT, maka selanjutnya membuat analisis SWOT dengan membandingkan antara faktor-faktor eksternal (peluang dan ancaman) dengan faktor-faktor internal (kekuatan dan kelemahan). Kombinasi faktor-faktor tersebut yaitu :

\section{Tabel 1. Stategi SO}

\begin{tabular}{|c|c|}
\hline & Kekuatan (Strengths) \\
\hline $\begin{array}{l}\text { Peluang } \\
\text { (Oppurtun } \\
\text { ities) }\end{array}$ & $\begin{array}{l}\text { 1. Mengembangkan daya tarik wisata } \\
\text { Pantai Lebih dan potensi persawahan, } \\
\text { hutan desa, sungai, lahan, serta } \\
\text { budaya dan sejarah yang dimiliki agar } \\
\text { dapat membuat Desa Wisata yang } \\
\text { berkelanjutan dan memiliki ciri khas. } \\
\text { 2. Menjalin kerjasama dengan media } \\
\text { massa untuk mempromosikan Pantai } \\
\text { Lebih dan potensi - potensi lainna } \\
\text { untuk mengenalkan apa yang dimiliki } \\
\text { serta meningkatkan kunjungan } \\
\text { wisatawan. } \\
\text { 3. Memberikan pengetahuan dan } \\
\text { pelatihan kepada masyarakat untuk } \\
\text { memahami pariwisata dan cara } \\
\text { mengembangkan potensi yang } \\
\text { dimiliki desanya, agar perkembangan } \\
\text { kepariwisataan di Desa Lebih bisa } \\
\text { berjalan dengan baik yang nantinya } \\
\text { dapat meningkatkan kesejahteraan } \\
\text { manyarakat Desa Lebih. } \\
\text { 4. Dapat bekerjasama dengan daya } \\
\text { tarik wisata lain yang berada } \\
\text { dikawasan parwisata Gianyar. }\end{array}$ \\
\hline
\end{tabular}

Tabel 2. Strategi ST

\begin{tabular}{|l|l|}
\hline & \multicolumn{2}{|c|}{ Kekuatan (Strengths) } \\
\hline & $\begin{array}{l}\text { 1. Mengembangkan daya tarik wisata } \\
\text { yang ramah lingkungan dan } \\
\text { berkelanjutan yang dapat mencegah }\end{array}$ \\
(Threats) & $\begin{array}{l}\text { terjadinya kerusakan lingkungan. } \\
\text { 2. Stakeholder terkait dapat } \\
\text { memberikan pelatihan kepada } \\
\text { masyarakat untuk menambah } \\
\text { pengetahuan akan pariwisata }\end{array}$ \\
\hline
\end{tabular}




\begin{tabular}{|l|l|}
\hline 3. Pengembangan Daya tarik wisata \\
dan potensi Desa Lebih harus \\
direncanakan dan dikemas dengan \\
baik sehingga dapat menjadi nilai plus \\
atau memiliki ciri khas yang \\
membedakan dari daya tarik wisata \\
lainnya. \\
4. Stakeholder di Desa Lebih harus \\
melakukan pengawasan terhadap \\
wisatawan dan penduduk pendatang \\
dengan menegakkan aturan terkait \\
kehidupan budaya dan adat istiadat \\
yang harus dihormati.
\end{tabular}

Tabel 3. Strategi Wo

\begin{tabular}{|c|c|}
\hline $\mathrm{E}$ & Kelemahan (Weaknesses) \\
\hline $\begin{array}{c}\text { Peluang } \\
\text { (Oppurtun } \\
\text { ities) }\end{array}$ & $\begin{array}{l}\text { 1. Melakukan kerjasama antara para } \\
\text { stakeholder, terkait dengan } \\
\text { pendanaan desa untuk pengembangan } \\
\text { desa wisata secara berkelanjutan. } \\
\text { Serta promosi yang bisa dimulai dari } \\
\text { masyarakat Desa lebih sendiri. } \\
\text { 2. Membangun dan mengoptimalkan } \\
\text { fasilitas fasilitas pendukung } \\
\text { pariwisata dengan manjalin } \\
\text { kerjasama ke berbagai sektor. Dari } \\
\text { masyarakatnya yaitu masyarakat } \\
\text { dapat berpartisipasi, salah satunya } \\
\text { dalam menyediakan akomodasi } \\
\text { seperti homestay, villa, dan lain } \\
\text { sebagainya. } \\
\text { 3. Meningkatkan kontribusi pengelola } \\
\text { Desa Wisata Lebih, salah satunya yaitu } \\
\text { Pokdarwis mengenai potensi wisata } \\
\text { yang dimiliki. Serta memberikan } \\
\text { pelatihan dan mengajak masyarakat } \\
\text { untuk berpartisipasi dalam } \\
\text { mengembangkan desanya. }\end{array}$ \\
\hline
\end{tabular}

Tabel 4. Strategi WT

\begin{tabular}{|c|c|}
\hline E & Kelemahan (Weaknesses) \\
\hline $\begin{array}{l}\text { Ancaman } \\
\text { (Threats) }\end{array}$ & $\begin{array}{l}\text { 1. Melakukan pengaturan dan } \\
\text { pengawasan yang tepat akan } \\
\text { pembangunan akomodasi, sarana \& } \\
\text { prasarana penunjang pariwisata agar } \\
\text { tidak memperburuk kondisi } \\
\text { lingkungan serta tidak mempengaruhi } \\
\text { kehidupan budaya dan adat istiadat } \\
\text { setempat. } \\
\text { 2. Meningkatkan kesadaran serta } \\
\text { mengoptimal- kan pentingnya } \\
\text { keterlibatan kerjasama semua } \\
\text { komponen stakeholder yang ada di } \\
\text { Desa Lebih. }\end{array}$ \\
\hline
\end{tabular}

\begin{tabular}{|l|l|}
\hline 3. Meningkatkan mutu sumber daya \\
manusia dan potensi-potensi yang \\
dimiliki agar menjadi bagian dari \\
kawasan pariwisata pesisir yang \\
menarik dan memiliki nilai jual.
\end{tabular}

\subsection{Prioritas Pengembangan Pariwisata}

Setelah mendapatkan strategi secara keseluruhan, maka dipilihlah strategi mana yang menjadi Prioritas Pengembangan Pariwisata di Desa Lebih berdasarkan pada hasil wawancara, observasi, kondisi eksisting serta hasil analisis SWOT yang sesuai dengan kenyataan dilapangan. Prioritas Pengembangan Pariwisata di Desa Lebih adalah sebagai berikut :

1. Mengembangkan daya tarik wisata Pantai Lebih dan potensi persawahan, hutan desa, sungai, lahan, serta budaya dan sejarah yang dimiliki agar dapat membuat Desa Wisata yang berkelanjutan dan memiliki ciri khas. Sebagai desa wisata baru perlu adanya pengembangan lebih lanjut diberbagai sektor agar Pantai Lebih dan kekayaan potensi-potensi lainnya dapat berkembang dengan baik dan menjadikan Desa Lebih sebagai desa wisata yang mempunyai atraksi yang beragam dan menarik.

2. Melakukan kerjasama antara para stakeholder, terkait dengan pendanaan desa untuk pengembangan desa wisata secara berkelanjutan. Serta promosi yang bisa dimulai dari masyarakat Desa lebih sendiri. Kendala utama dalam pengembangan pariwisata di Desa Lebih yaitu dari segi dana. Dana tersebut dibutuhkan untuk mengembangkan dan membangun sarana dan prasarana, akses, fasilitas dan lain sebagainya. Maka dari itu perlu adanya kerjasama dari segala pihak stakeholder terkait dengan pendanaan agar pengembangannya dapat berjalan dengan lancar.

3. Memberikan pengetahuan dan pelatihan kepada masyarakat untuk memahami pariwisata dan cara mengembangkan potensi yang dimiliki desanya, agar perkembangan kepariwisataan di Desa Lebih bisa berjalan dengan baik yang nantinya dapat meningkatkan kesejahteraan manyarakat Desa Lebih. Diperlukan peran dari segala pihak stakeholder agar memberikan pemahaman, pengetahuan, dan pelatihan mengenai kegiatan pariwisata yang akan berlangsung serta mengajak masyarakat untuk bersama-sama mengembangkan potensi yang dimiliki agar pengembangan Desa Wisata Lebih dapat berjalan dengan baik.

4. Membangun dan mengoptimalkan fasilitasfasilitas pendukung pariwisata dengan manjalin kerjasama ke berbagai sektor. Dari 
masyarakatnya yaitu masyarakat dapat berpartisipasi, salah satunya dalam menyediakan akomodasi seperti homestay, villa, dan lain sebagainya. Diperlukan adanya fasilitas-fasilitas sarana dan prasarana yang mendukung kegiatan pariwisata di Desa Lebih agar menunjang kebutuhan wisatawan yang berkunjung. Dengan berkerjasama ke berbagai sektor, diharapkan dapat membantu untuk membangun fasilitas-fasilitas tersebut tanpa merusak lingkungan sekitar serta tidak mempengaruhi adat istiadat setempat. Salah satunya yaitu dari masyarakat dapat membuat atau menyediakan homestay sekaligus mengenalkan ciri khas yang dimiliki Desa Lebih.

5. Menjalin kerjasama dengan media massa untuk mempromosikan Pantai Lebih dan potensipotensi lainnya untuk mengenalkan apa yang serta meningkatkan kunjungan wisatawan. Dengan perkembangnya Teknologi, Informasi dan Komunikasi yang semakin maju. Diharapkan kegiatan promosi dapat dilakukan dengan mudah oleh berbagai pihak terkait. Mempromosikan Desa Lebih dapat melalui kerjasama dengan media-media promosi atau promosi yang paling mudah yaitu melalui masyarakat Desa Lebih sendiri malalui media sosial untuk mengenalkan terlebih dahulu apa yang mereka miliki.

\section{KESIMPULAN}

\subsection{Simpulan}

Berdasarkan hasil penelitian yang telah dilakukan di Desa Wisata Lebih, mengenai Analisis Prioritas Pengembangan Pariwisata maka dapat diperoleh kesimpulan antara lain kondisi eksisting desa lebih yang dapat dilihat dari komponen 4A dan Analisis Prioritas Pengembangan Pariwisata di Desa Lebih dapat disimpulkan bahwa yang menjadi prioritas untuk dikembangkan terlebih dahulu yaitu mengembangkan lebih lanjut Pantai Lebih dan kekayaan potensi-potensi lainnya, melakukan kerjasama antar stakeholder terkait dengan pendanaan pengembangan, memberikan pemahaman dan pelatihan kepada masyarakat akan pariwisata, membangun dan mengoptimalkan fasilitas-fasilitas pendukung pariwisata guna menunjang kebutuhan wisatawan, dan melakukan promosi melalui media massa untuk mengenalkan potensi wisata yang dimiliki untuk meningkatkan kunjungan wisatawan serta peningkatan pengelolaan Desa Wisata yang terarah untuk kemajuan desa yang dapat meningkatkan kesejahteraan perekonomian masyarakat Desa Lebih.

\subsection{Saran}

Berdasarkan hasil penelitian yang telah dilakukan, penulis menyarankan beberapa hal yang kiranya dapat diterima. Adapun saran yang dapat diberikan antara lain yaitu saran kepada Pemerintah yaitu agar Pemerintah dapat membantu dalam pengembangan Desa Lebih menjadi Desa Wisata. Pemerintah dapat membantu dalam pemberian dana yang dapat digunakan untuk pengembangan potensi-potensi yang dimiliki, akses, fasilitas, serta aspek lainnya yang mendukung kegiatan pariwisata di Desa Lebih. Serta Pemerintah di harapkan dapat membantu memberikan pelatihan-pelatihan terkait dengan pariwisata kepada masyarakat lokal agar masyarakat lokal dapat memahami dengan baik serta dapat ikut berkontribusi dalam kegiatan pariwisata. Selanjutnya saran kepada Masyarakat Lokal yaitu agar Masyarakat lokal dapat ikut berkontribusi dalam pengembangan pariwisata di Desa lebih seperti, memberikan ide atau gagasan, memberikan kritik dan saran, serta ikut berpartisipasi dalam kegiatan pariwisata yang dalam pengembangannya nanti dapat memberikan manfaat yang positif bagi kesejahteraan perekonomian masyarakat Desa Lebih.

\section{DAFTAR PUSTAKA}

Arikunto, S. 2006. Prosedur Penelitian: Suatu Pendekatan Praktik. Jakarta: Rineka Cipta.

Bungin, Burhan. 2007. Analisis Data Penelitian Kualitatif. Jakarta : PT Grafindo Persada.

Bungin, Burhan. 2012. Analisis Data Penelitian Kualitatif. Jakarta : PT Grafindo Persada.

Cooper, Chris., et al. 1993. Tourism Principles \& Practice. Dalam Suwena \& Widyatmaja. 2010. Pengantar Dasar Ilmu Pariwisata. Denpasar: Udayana University Press.

David, Fred R. 2005. Strategic Management, Concept $\&$ Cases, $10^{\text {th }}$ edition. Prentice Hall. New Jersey.

Desi Ariani, Ni ketut dan Ida Bagus Suryawan. 2018. Perencanaan Pengembangan Kawasan Pariwisata Pantai Lebih, Desa Lebih, Kabupaten Gianyar. Fakultas Pariwisata, Universitas Udayana, Denpasar : Jurnal Destinasi Pariwisata, Vol. 6, No. 2, Hal. 258-263.

Delita, Fitra dan Elfayetti, Tumiar Sidauruk. 2017. Analisis SWOT untuk Strategi Pengembangan Obyek Wisata Pemandian Mual Mata Kecamatan Pematang Bndar Kabupaten Simalungun. Fakultas Ilmu Sosial, Universitas Negeri Medan, Sumatra Utara : Jurnal Geografi, Vol. 9, No. 1, Hal. 41-52.

Inskeep, E. 1991. Tourism Planning; An Integrated and Sustainable Development Approach, Van Nostrand Reinhold. 
Vol. 8 No 1, 2020

Kusmayadi dan Endar Sugiarto. 2000. Metodologi Penelitian dalam Bidang Kepariwisataan. Jakarta: PT Gramedia Pustaka Utama.

Kotler, Philip dan Gary Amstrong. 2008. Marketing An Intoduction (Eight Edition) Jilid 2. Terjemahan oleh Damos Sihombing. PT. Erlangga, Jakarta.

Kantor Desa Lebih. 2019. Profil Desa Lebih. GianyarBali.

Mahagangga, I Gusti Agung Oka. Kelembagaan Desa Wisata Pengabdian Kepada Masyarakat Di Desa Taro, Gianyar, Bali 25 Mei 2018. DOI: 10.13140/RG.2.2.23133.84967

Moleong, Lexi. 2012. Metodologi Penelitian Kualitatif. Bandung: PT. Remaja Rosdakarya

Rangkuti, Freddy. 2008. Analisis SWOT Teknik Membedah Kasus Bisnis. Jakarta: Penerbit PT Gramedia Pustaka Utama.

Swarbrooke, John. 1996. Pengembangan Pariwisata. Jakarta: Gramedia Pustaka Utama.

Tim Penyusun Kamus Pusat Bahasa Departemen Pendidikan Nasional. 2008. Kamus Besar Bahasa Indonesia. Jakarta: Balai Pustaka.

Undang-Undang No. 10 Tahun 2009 Tentang Kepariwisataan. 